\title{
A New Report on Sesarmid Crab Clistocoeloma villosum (Crustacea: Decapoda: Brachyura) from Korea
}

\author{
Sang-kyu Lee ${ }^{1}$, Jongwoo Jung ${ }^{2}$ and Won Kim ${ }^{1, *}$ \\ ${ }^{1}$ School of Biological Sciences, Seoul National University, Seoul 151-747, Korea \\ ${ }^{2}$ Department of Science Education, Ewha Womans University, Seoul 120-750, Korea
}

\begin{abstract}
As a result of continuous taxonomic study on crabs, Clistocoeloma villosum (A. Milne-Edwards, 1869) is newly reported from Korean waters. C. villosum has no epibranchial tooth on the carapace, while C. merguiense De Man, 1888, only recorded species of this genus in Korean fauna, has two epibranchial teeth. The description and illustrations of $C$. villosum are provided herein. Korean Sesarmid crabs now consist of 10 species belonging to six genera.
\end{abstract}

Keywords: new report, Clistocoeloma villosum, Decapoda, Korea

\section{INTRODUCTION}

Sesarmidae is one of the largest families of principally intertidal crabs. Nine species of sesarmid crabs belonging to six genera have been recorded in Korea: Chiromantes dehaani (H. Milne Edwards, 1953), C. haematocheir(De Haan, 1833), Clistocoeloma merguiense De Man, 1888, Nanosesarma minutum (De Man, 1887), Parasesarma erythodactyla (Hess, 1865), P. pictum (De Haan, 1835), P. plicatum (Latreille, 1803), Perisesarma bidens (De Haan, 1835), and Sesarmops intermedius (De Haan, 1835) (Kim, 1973; Kim and Kim, 1997). A continuous taxonomic study on crabs collected from Korea revealed that Clistocoeloma villosum (A. Milne-Edwards, 1869) is new to Korean fauna. Thus far, eight species belonging to the genus Clistocoeloma have been reported from across the world ( $\mathrm{Ng}$ et al., 2008). Among these, only C. merguiense has been recorded in Korea (Kim, 1973). The genus Clistocoeloma A. Milne-Edwards, 1873 is characterized by short, stiff, prominent setae-forming patches on the dorsal surface of the carapace and the ambulatory legs. This study describes and provides an illustration of $C$. villosum found in Korea. Currently, Korean Sesarmidae is composed of 10 species belonging to six genera.

All the specimens were preserved in $80 \%$ ethyl alcohol. The abbreviations "cl" and "cw" refer to the carapace length from the front to the posterior dorsal margin of the carapace and to the width of the carapace, respectively. Illustrations were prepared using a camera lucida. The materials examined in this study are deposited with the Marine Arthropod Depo-

*To whom correspondence should be addressed

Tel: 82-2-880-6695, Fax: 82-2-872-1993

E-mail: wonkim@plaza.snu.ac.kr sitory Bank of Korea (MADBK), Seoul National University.

\section{SYSTEMATIC ACCOUNT}

Family Sesarmidae Dana, 1851

Genus Clistocoeloma A. Milne-Edwards, 1873

${ }^{1 *}$ Clistocoeloma villosum (A. Milne Edwards, 1869)

Sesarma villosum A. Milne-Edwards, 1869: 31.

Sesarma (Holometopus) villosa: Tesch, 1917: 208, pl. 17, fig. 2.

Sesarma (Holometopus) villosum: Crosnier, 1965: 55, figs. 75, 76, 77a, 78 .

Chiromantes villosum: Nomoto et al., 1999: 9, pls.1-6; Ng and Liu, 1999: 299.

Clistocoeloma villosum: Davie, 2002: 221; Komai et al., 2004: 38, fig. 3 .

Material examined. 1 이 (cl $13.6 \mathrm{~mm}, \mathrm{cw} 16.2 \mathrm{~mm}), 2$ 우 우 (cl $12.1 \mathrm{~mm}$, cw $14.5 \mathrm{~mm}$; cl $10.8 \mathrm{~mm}$, cw $12.9 \mathrm{~mm}$ ), Gosan (Jejudo Is.), May 2003 (J. Jung).

Description. Carapace (Fig. 1A) squared; dorsal surface with numerous very short stiff setae often grouped in small patches; regions on dorsal surface poorly indicated; exorbital angle slightly produced and blunt; suborbital margin covered with very short setae and tiny granules; lateral branchial ridges absent; lateral margin slightly sinuous on anterior part, without trace of epibranchial tooth. Front moderately deflexed, with faint median notch. Antennule and antenna contiguous. Basal antennular segment subrectangular. Antenna set oblique; flagellum relatively long, extending into orbit. Third maxilliped (Fig. 1G) with well-developed flagellum on exopod.

$1 *$ 단모뭉치게 (신칭) 


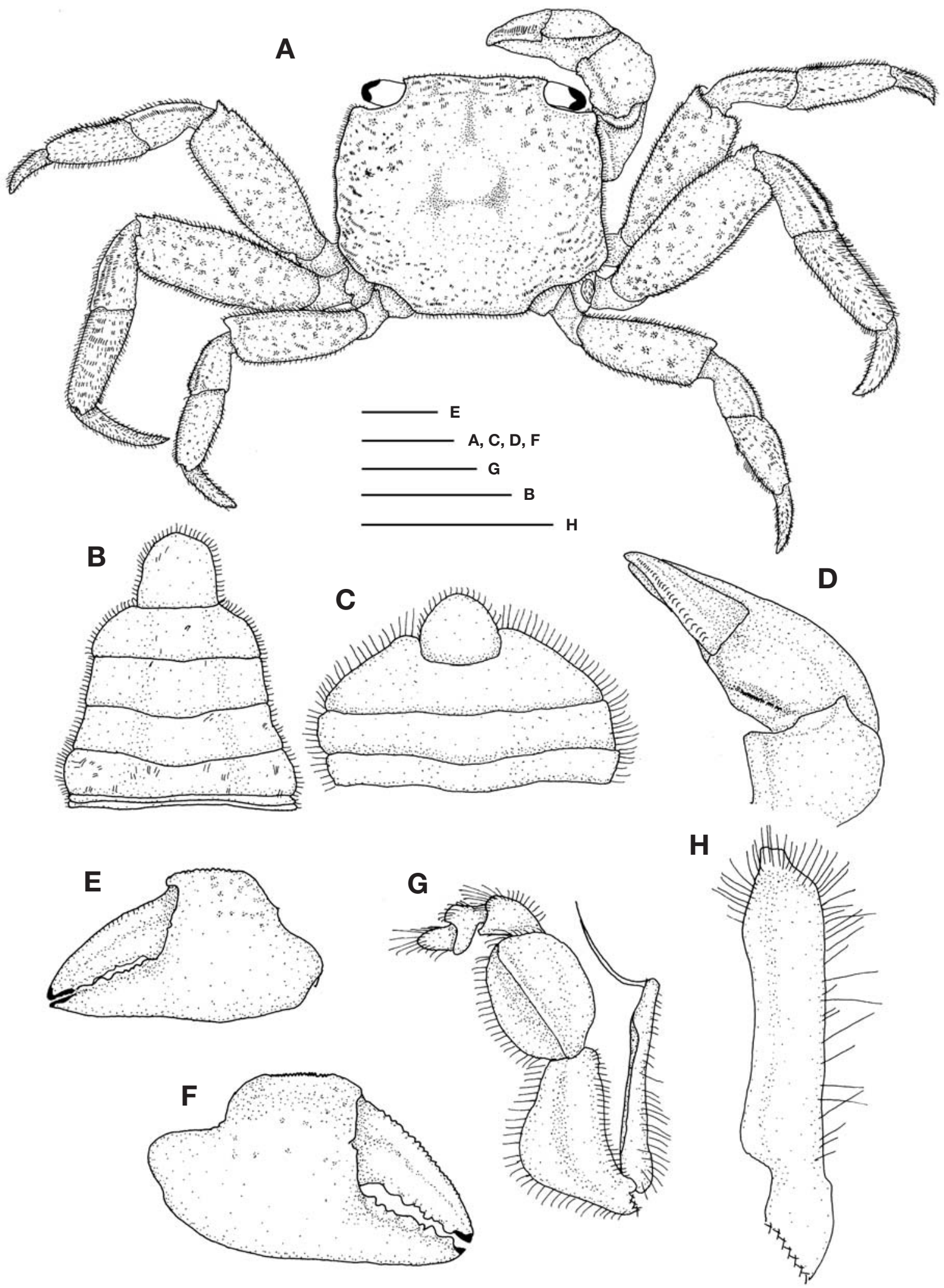

Fig. 1. Clistocoeloma villosum (A. Milne Edwards, 1869). A, whole animal, dorsal view, male; B, abdomen of male; C, abdomen of female; $D$, right cheliped of male, dorsal view; $E$, left cheliped of female, outer view; $F$, right cheliped of male, outer view; $G$, left third maxilliped, male; $H$, left first pleopod, ventral view, male. Scale bars=2 mm (G, E, H), $3 \mathrm{~mm}(C, D, F), 5 \mathrm{~mm}(A, B)$. 
Chelipeds of male (Fig. 1A, 1D, 1F) subequal. Merus weakly tuberculate on inner ventral margin; dorsal margin sharply carinate, with row of very short stiff setae and row of granules. Inner angle of carpus with weakly produced in rounded lobe; dorsal surface of carpus with scattered small patches of short setae. Dorsal surface of palm with sharp and partially pectinated ridge composed of 15 small corneous teeth medially, bearing small tubercles distally and proximally. Dactylus straight; cutting edge with row of small and rounded teeth; dorsal surface bearing 25 tubercles becoming lower toward tip; outer surface of dactylus smooth. Cheliped of females (Fig. 1E) smaller than those of male. Palm lacking pectinated corneous teeth. Dactylus with 12-16 very small tubercles becoming lower toward tip.

Ambulatory legs (Fig. 1A) moderately short, covered with short stiff setae. Each merus armed with low blunt subdistal projection on anterior border; dorsal surfaces of meri with sparse very short setae and scattered small patches of short setae. Carpi with 1 or 2 lines of short stiff setae on dorsal surface. Propodi stout, each with numerous short stiff setae and rows of longish setae on surfaces, but without corneous spinules. Dactyli lacking corneous spines, but with covering of short stiff setae and rows of longish setae.

Abdomen of male (Fig. 1B) widely narrowed. Sixth abdominal somite as long as fifth somite. Telson distinctly longer than width. Abdomen of female (Fig. 1C) with telson evenly rounded, as long as basal width and longer than mid-line length of sixth abdominal somite.

First gonopod (Fig. 1H) stout, nearly straight; terminal process short, with shallow notch distally.

Remarks. Thus far, eight species belonging to the genus Clistocoeloma have been recorded ( $\mathrm{Ng}$ et al., 2008). C. villosum can be readily distinguished from other 6 species since it does not have epibranchial teeth on the carapace, whereas they have two epibranchial teeth and a postorbital tooth on the carapace [Clistocoeloma amamaparense Rahayu and Takeda, 2000; C. balansae A. Milne-Edwards, 1873; $C$. lanatum (Alcock, 1900); C. merguiense De Man, 1888; $C$. sinense Shen, 1933; and C. tectum (Rathbun, 1914)]. Remaining one species, C. suvaense Edmonson, 1951, also shows little evidence of epibranchial teeth. In the case of our male specimen, there was a faint trace of epibranchial teeth on the lateral border of the carapace, but the characteristics of this specimen agreed quite well with other characteristics of $C$. villosum (A. Milne Edwards, 1869).

Tesch (1917) and Komai et al. (2004) reported that the chelipeds of male have 20-30 corneous teeth on the dorsal surface of the palm, whereas Crosonier (1965) reported that males have 15-16 teeth. The present male specimen has 15 corneous teeth on the dorsal surface of the palm.
Habitat. Slightly moist soil under fallen leaves.

Distribution. Madagascar, Sumatra, Japan, New Guinea, Australia, Samoa Islands, and Korea (present study).

\section{ACKNOWLEDGEMENTS}

This work was supported by a grant from Marine Biotechnology Programme Funded by Ministry of Land, Transport. The authors are thankful to Prof. D. Guinot, Prof. H.-T. Shin, and Dr. H. Komatsu to providing for their comments and for providing references for this work.

\section{REFERENCES}

Crosnier, A., 1965. Crustacés Décapodes Grapsidae et Ocypodidae. Faune de Madagascar, 18: 1-143.

Davie, P.J.F., 2002. Zoological Catalogue of Australia, Vol. 19. 3B. Crustacea: Malacostraca: Eucarida (Part2): Decapoda-Anomura, Brachyura. CSIRO Publishing, Canberra, pp. 1-641.

Kim, H.S., 1973. Illustrated encyclopedia of fauna and flora of Korea. Samwha publishing co, Seoul. Vol. 14. AnomuraBrachyura. pp. 1-649.

Kim, W. and H.S. Kim, 1997. Lists of animals in Korea (excluding insects). Korean Sco. Syst. Zool., Seoul, pp. 212-233.

Komai, T., T. Nagai, A. Yogi, T. Naruse, Y. Fujita and S. Shokita, 2004. New records of four grapsid crabs (Crustacea: Decapoda: Brachyura) from Japan, with notes on four rare species. Nat. Hist. Res., 8(1): 33-63.

Milne-Edwards, A., 1869. Note sur quelques nouvelles especes de genre Sesarma Say. Nouv. Arch. Mus. Hist. Nat., Paris, 5: $25-31$.

Ng, P.K.L. and H.-C. Liu, 1999. The taxonomy of Sesarma tangi Rathbun, 1831 and S. stormi De Man, 1895 (Crustacea: Decapoda: Brachyura: Grapsidae: Sesarminae), with establishment of a new genus for S. stormi. Zool. Studies, 38(2): 228237.

Ng, P.K.L., D. Guinot and P.J.F. Davie, 2008. Systema brachyurorum: Part 1. An annotated checklist of extant brachyuran crabs of the world. Raff. Bull. Zool., 17: 1-286.

Nomoto, A., S. Todo, S. Kimura, T. Kishino, M. Sakano and K. Wada, 1999. Six rare brachyuran species of the family Grapdidae, recorded from the Kinokawa river estuary, Wakayama Prefecture. Nankiseibutu, 41(1): 5-9.

Tesch, J.J., 1917. Synopsis of the genera Sesarma, Metasesarma, Sarmatium and Clistocoeloma with a key to determination of the Undo-Pacific species. Zool. Meded., 3(2-3): 127260.

Received June 22, 2010 Accepted July 8, 201 